\title{
Who is benefiting more from common property forest resources: poor or less poor?
}

\begin{abstract}
A.R. Bhandari ${ }^{1}$, and H. Uibrig ${ }^{2}$,
This paper intends to assess the distribution of community forestry benefits among economic groups of the users comparing protected area buffer zone with the Department of Forests regime in Nepal. Following the case study approach two forest user groups of Nawalparasi district, each from buffer zone of Chitwan National Park and Department of Forests regime were selected for the study. The study results suggest that the users in the buffer zone receive less benefit from community forestry than the users in the Department of Forests regime. Analysis of inputs and outputs reveals that poor households receive less benefit than the better off households in both of the regimes. Insofar the results counteract the principles of equity as expected from national forest policy goals and approaches.
\end{abstract}

Key words: benefits, buffer zone, community forestry, equity, heterogeneity, Nepal.

D espite the arguments of the Tragedy of the Commons (Hardin, 1968) in favor of privatization or government control over common goods for their protection, community based natural resource management strategies are growingly implemented in developing countries. Community Forestry (CF) is such an effort, in Nepal, evolved as one of the main components of country's forest development strategy during past two decades. Nepal was one of the first countries to embrace fully community forestry as the main strategy of its national forest policy (Bartlett, 1992). Local communities have usufruct right over the forest resources through a forest user group (FUG), group involving all members of the community that regularly use a forest to meet their household needs. The Forest Act 1993 and Forest Regulation 1995 have legitimized the roles, responsibilities and rights of FUGs as an independent, autonomous and selfgoverning institution responsible to protect, manage and sustainable use the community forest. So far more than 14,000 FUGs, which constitute about 35\% of the population of the country, are managing about 1.20 million ha of forest, about $25 \%$ of the country's total forest land (DoF, 2007). Master Plan for Forestry Sector (MPFS), implemented in 1989, recognize about $60 \%$ of the country's forest as potential community forests.

Nepal is actively involved in environment protection and biodiversity conservation through establishing network of protected areas in the country. Till date $19.70 \%$ of the country's total area has been declared as protected areas (ICIMOD/MOEST, 2007). Community participation in protected area management has been initiated through buffer zone program in the country since 1996. Buffer Zone (BZ) is a designated area surrounding a national park or reserve within which the use of forest products by local people is regulated to ensure sustainability of the resources, environmental conservation and community development (NBS, 2002). So far 11 buffer zones have been declared in Nepal constituting $17.52 \%$ of the protected areas and $3.45 \%$ of the total area of the country (DNPWC/PCP, 2006). In buffer zone, community forestry program has been implemented as one of the most important programs.

The Tenth Plan (2002-2007) and Poverty Reduction Strategy Paper (PRSP, 2002) provide the strategic vision, enabling policy framework for decentralization and legitimate the local efforts by devolving and sharing power of the state with the dependent communities. CF program in Nepal is based on the principle of devolution, and it is an attempt to improve the socio-economic conditions of rural communities and halt environmental degradation. Despite the successful development of CF in Nepal there are instances when not all people receive the same benefits that could be conducive to discussion of equity issues within FUGs (Richards et al., 2003). Equity in benefit distribution of community forest

\footnotetext{
General Secretary, Green Governance Nepal. Email: anantarb@yahoo.com

${ }^{2}$ Professor, Dresden University of Technology, Germany. Email: druibrig@forst.tu-dresden.de
} 
management is considered to be one of the major determinants of long-term sustainability. This study aims to assess the distributional implications of CF benefits among different economic groups of the users comparing protected area buffer zone with the department of forest regime in Nepal.

\section{Materials and methods}

This study was carried out in the buffer zone of Chitwan National Park and its vicinity in Nawalparasi district of western Nepal. Kalika FUG from buffer zone and Choutari FUG from Department of Forest regime were selected for the study considering similar forest types and socio-economic conditions of the users.

Structured questionnaire survey, most widely used and popular technique in social research (Neuman, 1994), was conducted to collect the primary data. Pretested questionnaire was filled up through visiting the households during the field visits between October 2006 and February 2007. A total of 131 households, 60 from Kalika FUG and 71 from Choutari FUG, about 10\% of total, were selected through stratified random sampling based on wealth ranking for the survey. Participants in the participatory rural appraisal exercise were asked to categorize all households into three different wealth groups, poor, middle class and better off based on the criteria that they considered important for such classification. Six semi-structured interviews and four focus group discussions were conducted with the key informants to triangulate the data. Numerous literatures and documents were reviewed to collect the secondary data.

The data were analyzed through benefit-cost ratio, Mann-Whitney test, Kruskal-Wallis test and $C^{2}$ Approximation. Benefits and costs were assessed at household level among different economic groups. Benefit is defined as all direct and tangible products received by users' household viz. timber, fuelwood, fodder, grass, leaf litter, and other non-timber forest products (NTFP). The valuation of the products was done based on the local market rates. Cost is defined as all forest protection and management costs incurred by the users. Forest protection and management costs involve product/operating costs and transaction costs. Product/operating costs include fees or charges paid by the users to FUG, time spent by the households in collecting forest products, and the labor input to protect and manage forests. Transaction costs include time spent by the households in meetings and assemblies of the FUG. Labor costs and transaction costs were determined by the opportunity costs of labor at local level. The benefits and costs of individual households of different economic groups were quantified and averaged to determine the benefits and costs of the households of each group.

\section{Results and discussion}

The main results of the study on costs and benefits referring to the two different regimes of management have been listed. Table 1 provides an overview on the respective figures, which is explained and discussed in the following paragraphs.

Table 1. Community forestry benefits and costs of households

\begin{tabular}{|c|c|c|c|c|c|c|}
\hline \multicolumn{7}{|c|}{ Average Annual Costs and Benefits of Household in US\$* } \\
\hline & & Group of Households & Better Off & Middle Class & Poor & Total Average \\
\hline \multirow{6}{*}{ 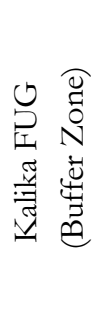 } & \multirow[t]{2}{*}{ Benefit } & Total & 131.2 & 18.5 & 5.5 & 35.5 \\
\hline & & Net & 79.3 & 11.6 & 0.2 & 20.8 \\
\hline & \multirow[t]{3}{*}{ Cost } & Product/Operating & 41.4 & 4.1 & 2.7 & 10.5 \\
\hline & & Transaction & 10.4 & 2.8 & 2.6 & 4.2 \\
\hline & & Total & 51.9 & 6.9 & 5.3 & 14.7 \\
\hline & \multicolumn{2}{|c|}{ Benefit-Cost Ratio } & 2.53 & 2.69 & 1.04 & 2.19 \\
\hline \multirow{6}{*}{ 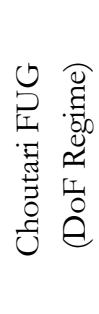 } & \multirow[t]{2}{*}{ Benefit } & Total & 486.4 & 175.8 & 24.3 & 183.3 \\
\hline & & Net & 343.4 & 126.7 & 11.6 & 129.7 \\
\hline & \multirow[t]{3}{*}{ Cost } & Product/Operating & 133.2 & 43.7 & 9.2 & 48.0 \\
\hline & & Transaction & 9.8 & 5.4 & 3.6 & 5.6 \\
\hline & & Total & 143.1 & 49.1 & 12.7 & 53.6 \\
\hline & \multicolumn{2}{|c|}{ Benefit-Cost Ratio } & 3.40 & 3.58 & 1.91 & 3.16 \\
\hline
\end{tabular}

$* 1 U S \$=R S 73$ in 2006 


\section{Community forestry costs}

Average total costs of a household of Kalika FUG and Choutari FUG with regard to community forestry is US\$14.7 and US \$ 53.6 per year respectively. Higher total costs in the DoF regime is mainly due to the high product/operating costs. Less forest products are extracted from the CF in the buffer zone and results in low product/operating costs. Product/ operating costs of a household reflects the situation of products consumption by the household. Average annual product/operating costs of better off household is fairly high in both of the FUGs. It indicates that wealthier households consume more forest products than poor households.

Transaction costs is considered as an indicator of participation in CF process, particularly in decisionmaking. Annual transaction costs of Kalika FUG and Choutari FUG is US\$ 4.2 and US\$ 5.6 respectively. The differences in transaction costs between the two regimes is a result of forest management activities. The lesser the management activities the lesser the transaction costs. Transaction costs also varies between the economic groups of the users. Better off household incur three times higher transaction costs than that of poor household in both FUGs. It indicates that poor households have less influence in decision-making process in community forestry.

\section{Management regimes and community forestry benefits}

Household benefit from community forestry in the buffer zone is fairly less than the DoF regime. Average annual CF benefit of a household of Kalika FUG and Choutari FUG is US\$ 35.5 and US $\$ 183.3$ respectively. Annual household net benefit from CF of Kalika FUG and Choutari FUG is US\$20.8 and US\$ 129.7 respectively. Mann-Whitney test suggests that annual total and net CF benefit significantly differs between the buffer zone and the DoF regime $(p<0.000)$. Average benefit-cost ratio of a household of Kalika FUG and Choutari FUG is 2.19 and 3.16 respectively. Mann-Whitney test suggests that benefitcost ratio significantly differs between the two FUGs $(p<0.005)$. Lower benefit-cost ratio of the users in the buffer zone implies their high contribution in the CF but less outputs as compared to the outside. This analysis reveals that CF benefits varied between the buffer zone and the DoF regime; and FUG members in the buffer zone obtain fewer benefits from $\mathrm{CF}$ than the members in the DoF regime.
Buffer zone complements the national park in the conservation of biological resources and extension of wildlife habitat. It was observed that community forestry program in the buffer zone is focused, more prominently, on conserving forest resources. Harvesting and extraction of forest products are regulated through a more restrictive rules and practices in the buffer zone. It is clearly seen in the studied CF that the duration of harvesting and extraction of forest products is lesser in the buffer zone than in the DoF regime even though socioeconomic condition of the households and per unit stocking is comparable. Extraction of fuelwood is practiced once a year (7-15 days) in Kalika CF whereas it is practiced twice a year (15-30 days) in Choutari CF. Similarly, fodder and grass from CF is extracted during 3-6 months per year in Kalika CF and up to 9 months per year in Choutari CF. It is obvious that longer duration offers, to the users, in collecting more products from community forest.

Economic and livelihood opportunities through forest products are higher in DoF regime since they can sell forest products elsewhere and generate fund for forest management and community development. But, in the buffer zone, Rule 24 (7) of Buffer Zone Management Regulation 1996 prohibits to selling timber and fuelwood, the major sources of income for FUG, outside the zone.

Government of Nepal has implemented a pro-public policy in protected area management with the provision of $30-50 \%$ national park income allocating to buffer zone. This fund is aimed for resource management and community development in buffer zone through public participation. About US\$ $2,330,000$ has been spent in the buffer zone of Chitwan National Park during the last 8 years. This fund has been utilized for various community development activities such as maintenance of irrigation, water supply, rural road/trail, river training and bio-gas installation. Although this fund does not contribute, substantially, to the household income of the users, it has a contribution in rural development and makes people's attitude positive towards resource conservation (Gurung et al., 2004).

FUG generate fund through charging products price to the members and selling surplus forest products (in the buffer zone product selling is not allowed outside the zone). Kalika FUG generates US\$2687.03 while Choutari FUG generates US\$ 18123.88 per year, 
although it oscillates. This fund has been utilized for forest management and community development activities focusing livelihood opportunities of the users. Buffer zone fund contributes to the users in this aspect, and, shrinks the CF income gap between the buffer zone and the DoF regime. The communities belonging to studied FUG in the buffer zone received US\$ 4470.90 during the fiscal year 2005/06 from the national park income, through buffer zone program, albeit it fluctuates year to year.

In the past, local communities in the buffer zone relied on the national park for their forest products needs. After establishment of the national park, the extraction of resources is prohibited. However, national park authority opens up the park for 3 days in a year to the buffer zone people who can collect thatch grass/reeds. Thatch grass is very useful, particularly for poor and indigenous households, to construct and repair houses and cattle shades. In the studied FUG, it contributes roughly US\$ 12 to a household in a year and complements to CF benefits in the buffer zone.

Total annual CF benefits of a household in Kalika FUG, after including per capita FUG fund, per capita buffer zone fund and value of the products extracted from the national park, is US\$77.76. Similarly, total annual CF benefits of a household in Choutari FUG after including per capita FUG fund is US\$ 206.95. It reveals that the household level CF benefit of the FUG members in the buffer zone is fairly less than the FUG members in the DoF regime.

\section{Economic heterogeneity and community forestry benefits}

Annual CF benefit of better off household is fairly large followed by middle class groups in both FUGs. Poor households receive fairly less amount of benefits per year from CF. Annual total CF benefit of better off, middle class and poor household in Kalika FUG is US\$ 131.20, US\$ 18.50 and US\$ 5.53 respectively while in Choutari FUG it is US\$ 486.44, US\$ 175.83 and US\$ 24.25 respectively. The distribution of annual net benefits among economic groups is similar to the distribution of annual total CF benefits in both FUGs. Kruskal-Wallis test suggests that total and net CF benefit significantly differs among economic groups of both Kalika FUG $(\mathrm{p}<0.000)$ and Choutari FUG $(\mathrm{p}<0.000) . \mathrm{C}^{2}-$ Approximation, a method of multiple pair wise comparison of mean rank (Sachs, 1997), has been applied to identify which economic group significantly differs in terms of CF benefits. It suggests that total and net CF benefit significantly differs between better off and poor, better off and middle class and middle class and poor households in both FUGs.

Benefit-cost ratio of the households of middle class group is higher than the poor and slightly higher than the better off households in both FUGs. It implies that middle class households are more efficient. Kruskal-Wallis test suggests that benefit-cost ratio differs significantly between the three economic groups in Kalika FUG ( $<<0.002)$ and Choutari FUG $(\mathrm{p}<0.021)$. Ç ${ }^{2}-$ Approximation suggests that it significantly varies between better off and poor, and middle class and poor while the difference between better off and middle class is not statistically significant in both FUGs.

This analysis indicates that the distribution of CF benefits is unequal and influenced by the economic heterogeneity of the users; consequently, poor receive lesser benefits from CF than the better off households in both of the regimes. In buffer zone poor people are suffering more. In the past, poor and indigenous people in the buffer zone were depending on national park for forest resources. After the restriction of resource extraction from national park, they were drawing their livelihoods from the forest resources in the buffer zone. When community forestry was brought as a major component of buffer zone program, in which they have limited influence, access has been controlled and regulated.

Better off households consume more forest products such as fodder, grass and leaf litter since they have larger number of livestock and bigger landholdings than the poor. However, forest products available in the private land complement, to some extent, to the better off households. The poor households have small landholdings and rely on community forest for such products albeit they consume less. Wealthier households consume timber for constructing new houses or repairing the old ones, and cattle shades, and domestic furniture. On the contrary, poor households have low priority in constructing and improving the houses and furniture, and hence have less demand for timber. In the past, poor people in the locality used to collect fuelwood from the forest and sell to the market for their livelihood. But, after handing over the forests to the communities the extraction of the fuelwood has been regulated. It is 
observed that poor households are not able to internalize the benefits from forest products currently available in community forests. And, there is no any compensation mechanism in the $\mathrm{CF}$ to increase the benefits of the poor who utilize limited quantity of forest products. This finding supports the conclusion drawn by Richards et al. (1999) that poor households are currently benefiting less from community forestry of Nepal.

Another reason why poor people receive lower benefits is their lower participation in CF decisionmaking process. Transaction cost, which is an indicator of participation in decision-making process, is less of the poor than that of middle class and better off households. The distribution of transaction cost is similar in the buffer zone and the DoF regime. In addition, the poor bear less total costs, which indicate their less involvement in the entire process of community forestry. The less participation of the poor in community forestry process is due to high rate of time preference and high opportunity cost of time and labor which is allocated to secure immediate livelihood needs.

\section{Conclusions}

This study reveals that users in the buffer zone obtain fewer benefits from community forestry than that of the Department of Forests regime. FUGs of the DoF regime are more autonomous than that of the buffer zones which are subjected to a higher level of restrictions. Withdrawal and management rights are more restrictive in the buffer zone due to the emphasis on conservation of biological resources and extension of wildlife habitat. On the other hand, FUGs in the DoF regime are intended to maximize the product extraction. Economic and livelihood opportunities through forest products are higher in the DoF regime since they sell surplus products in the market, but, in the buffer zone, the sell of timber and fuelwood is prohibited outside the zone. However, $30-50 \%$ national park income that is ploughed back to the buffer zone contributes in resource management and development activities within the zone.

This study suggests that current distribution practice of community forestry benefit is not equitable and counteracts national forest policy goals and approaches. Poor households receive lesser benefits from community forestry than the better off households. Furthermore, poor people in the buffer zone are suffering more due to the higher level of confines in community forestry.

\section{Reference}

Bartlett, A. G. 1992. A review of community forestry advances in Nepal. Commonwealth Forestry Review 71(2): 95-100.

DNPWC/PCP. 2006. Annual report. Participatory Conservation Program. DNPWC/ UNDP Nepal.

DoF, 2007. MIS database of Department of Forest, Babarmahal, Kathmandu, Nepal.

Gurung, H.; Shah, S.G.; Subba, C.; Adhikari, S.P. and Dhungana, S.K. 2004. Impact assessment of buffer zone program in Nepal. New ERA, Kathmandu, Nepal.

Hardin, G. 1968. The tragedy of the commons. Science 162: $1243-1248$

GON. 1973. National Parks and Wildlife Conservation Act, 1973. His Majesty's Government of Nepal (HMGN), Kathmandu.

GON. 1993. Forest Act, 1993. His Majesty's Government of Nepal (HMGN), Kathmandu.

GON. 1995. Forest Regulations, 1995. Government of Nepal (GON), Kathmandu.

GON. 1996. The Buffer Zone Management Regulations, 1996. Government of Nepal (GON), Kathmandu.

ICIMOD/MOEST. 2007. Nepal Biodiversity Resource Book: Protected Areas, Ramsar Sites and World Heritage Sites. International Center for Integrated Mountain Development (ICIMOD) and Ministry of Environment, Science and Technology (MOEST), Government of Nepal, Kathmandu.

MPFS. 1989. Master Plan for the Forestry Sector. His Majesty's Government of Nepal, Kathmandu.

NBS. 2002. Nepal Biodiversity Strategy. Ministry of Forests and Soil Conservation, GON Nepal.

Neuman, L.W. 1994. Social Research Methods: Qualitative and Quantitative Approaches. Allyn and Bacon Boston. NPC. 2002. Poverty Reduction Strategy. The National Planning Commission (NPC). Government of Nepal, Kathmandu. 
NPC. 2002. Poverty Reduction Strategy. The National Planning Commission (NPC). Government of Nepal, Kathmandu.

NPC. 2002. The Tenth Plan (2002-2007). The National Planning Commission (NPC). Government of Nepal, Kathmandu.

Richards, M.; Kanel, K.; Maharjan, M. and Davies, J. 1999. Towards participatory economic analysis by forest users groups in Nepal. Overseas Development Institute, London, UK.

Richards, M.; Maharjan, M.; and Kanel, K. 2003. Economics, poverty and transparency: measuring equity in forest user groups. Journal of Forest and Livelihood 3(1).

Sachs, L. 1997. Angewandte statistik, 8. Auflage. Springer-Verlos, Berlin. 